\title{
A REVIEW OF THE CIVIL SERVICE LAWS OF THE UNITED STATES
}

\author{
BY ALBERT SMITH FAUGHT \\ Philadelphia
}

I

$\Omega^{H}$

HE point of greatest weakness in a republican form of government lies in the methods adopted for selecting the persons entrusted with the governmental machinery. The criticism that democracy as exemplified in America is still on trial and has not yet demonstrated its superiority over rival systems which have flourished in the old world countries finds its strongest justification in the disordered political conditions which persistently manifest themselves in the United States. The people of America are not oblivious as to the possible existence of defects in their system of government, and recent years have witnessed conscious efforts on the part of states and communities to study actual political conditions that they may be improved by remedial and preventive legislation.

The division of the American Commonwealth into innumerable states and partly autonomous municipalities, able within certain limits to propound and try out legislative or administrative remedies for the cure of political evils and abuses, has operated towards converting each into a political and sociological laboratory for the investigation of governmental problems. The scientific method of original experimental research is thus in effect being applied throughout the United States to the study of actual political conditions. The fact that the American people whose political conditions are being investigated are at the same time themselves the investigators is a unique feature. The complexity of political conditions is such that each step forward or backward in the solution of governmental problems doubly augments or retards the power of the people to achieve the next step.

Public officials and employees under a republican form of government can be selected only by one of two methods, or by a combination of them, namely by election or by appointment. Since men are said to be born free and equal, heredity is not recognized in a republic as an additional mode of selecting office holders, although perhaps it is allowed surreptitiously to exert its influence in "grandfather" clauses and in the preference given to veterans' orphans in making appointments to office. Restricted to the two methods, election and appointment, the results of legislative efforts at regulating the selection of public officials are found

1 Member of Council of National Civil Service Reform League. 
upon the statute books of the various states in the form of election laws and acts establishing civil service systems.

The two available methods, election and appointment, for choosing public officers are capable of being combined in many ways. At one extreme any citizen may be eligible for an office filled at an election in which all adult citizens of a community, men and women alike, participate. Restrictions as to age, sex, education, property and other qualifications may be imposed in determining the electorate. The indirect election of the president of the United States by members of the electoral college, who alone have the right to cast legal votes for the incumbent of that office, was originally intended as an extreme restriction on the electorate for this most important office. If the electoral college had been allowed to become a deliberative body with real power to chose the president this method of election would closely resemble the modern system of appointment of public employees by a small city council of a municipality under the commission form of government. If the group having the power to elect or appoint be further restricted, we reach the typical case of a public officer having the sole right to appoint others to office, the whole power of election becoming concentrated in one individual.

Restrictions may also be imposed upon those who are eligible for election or appointment. We here enter the domain of civil service laws. Either rigid limitations may be established as to residence, age, experience and various other matters; or relative and preferential restrictions may be imposed by favoring certain classes of citizens for appointment, such as veterans in Wisconsin, "where practicable, other conditions being equal," or persons injured in the public service as in Los Angeles. The extreme restriction upon the privilege of appointing public officials is the requiring of appointment to office of a particular person to be designated by a process eliminating completely or as far as possible every element of discretion. Usually under civil service laws, the appointing officer has a choice among the three highest available names on the appropriate eligible list, but in Illinois the statute requires the appointment of the particular individual who has attained the highest mark or rating after a competitive examination. Another extreme limitation upon the power of selecting public officers and avoidance of personal discretion in making appointments is also attained by the Chicago civil service law which allows laborers to be selected by lot from among those on the appropriate eligible list.

In the forum of public opinion to-day there are being discussed the merits and defects of many important experiments in selecting and removing public officials such as the non-partisan primary, the proportional representation plan of electing a city council, the recall of judges and the establishment of civil service systems. The nation as a whole recognizes 
the evils and dangers which accompany the old order of government by political machines maintained by election frauds and chicanery and supported by the spoils system. As to the proper remedies, there is still wide divergence of opinion, and we have not yet obtained a final answer to Tweed's question as to what we are going to do about it.

It is clear that the problem of election law and that of civil service law are but two phases of one of the greatest problems of a democracy, the choosing of just and efficient administrators of the machinery of government. Space does not permit the adequate consideration of either of these two subjects. The current discussion of the drafting of a model civil service law [Footnote: see the Consideration of the Draft cf a Model Civil Service Law Proposed by Mr. Robert C. Catherwood, page 377 of this issue] renders the present time opportune for a brief review of certain of the civil service laws and systems in force in the United States. Among the wide diversity of legislative experiments, it may be possible to point out certain tendencies pointing towards the recognition of essential features of effective civil service systems.

\section{II}

The United States Civil Service Commission ${ }^{2}$ concisely reviews the present extent of civil service in the United States in the following language: "Of the whole number of public employees in the United States-federal, state, county, municipal and village-not far from 600,000 , or nearly two thirds of the entire number, are withdrawn from the spoils system and appointed upon a merit basis, under laws intended to regulate and improve the public service. The experience obtained in the administration of the merit system by more than two hundred civil service commissions under varying conditions has demonstrated the value and the success of the system of obtaining well-qualified persons for all classes of positions, including the higher expert positions."

Almost thirty different types of civil service laws may to-day be found in actual operation in the United States. A wide variety of methods and principles, not always consistent with each other, are found embodied in these acts. The object to be attained is presumed to be the same in each case and may be summarized as follows: (1) to increase the effectiveness and economy of work done by public officials by weeding out incompetents and allowing the appointment only of those who are fully competent to perform the required duties; (2) to minimize the waste due to frequent changes in administrations by making permanent the tenure of office of competent public employees; (3) to minimize the danger of public officeholders maintaining themselves in office by improper political methods and of being paid out of the public treasury for

: Twenty-ninth Annual Report (1912), page 38. 
service rendered to a political party instead of for work performed as public employees for the community as a whole; (4) to encourage faithful service to the community by rewarding it with promotion and permanency in office; (5) to protect public officers from outside political pressure so that they may devote all their time and energy to their public duties and be free from any obligation to make political contributions or render political service as a condition of continuance in office; and (6) to establish equitable methods of giving every man of equal ability equal opportunities of obtaining desirable positions in the public service.

The civil service laws now in force in the United States have been enacted by many types of law making bodies. The federal civil service law, including the District of Columbia and the outlying possessions, is based upon acts of Congress, the first of which was passed on January 16,1883 , as the result of widespread agitation against the spoils system which had evolved a disappointed office-seeker as an assassin of President Garfield. The United States Civil Service Commission, appointed and removed at the pleasure of the President, is the administrative head of the federal system which now has jurisdiction over 273,000 persons in the employment of the United States government.

In the constitutions of three states are embodied civil service requirements:-New York, adopted on November 6, 1894; Colorado, amendment of 1902; and Ohio, adopted on September 3, 1912. Article 15, section 10 of the Ohio constitution reads: "Appointments and promotions in the civil service of the state, the several counties, and cities shall be made according to merit and fitness, to be ascertained, asfar as practicable, by competitive examinations. Laws shall be passed providing for the enforcement of this provision." The New York constitutional provision contains an additional clause giving special preference and protection to veterans. The principle that old soldiers of the United States should form a caste of favored citizens may have its value in encouraging military service but it is not one which has any immediate connection with the principles which have led to the extension of the civil service system as a means of selecting public officials in the democracy of the American people. The Superior Court of Pennsylvania in the case of Wood v. Mulholland, ${ }^{3}$ decided that the clause of the Philadelphia civil service law which exempted from its operation veterans and the widows and children of veterans was unconstitutional as granting privileges to a sfecial class but whether the New York constitutional preference of veterans is in violation of the United States Constitution has never been decided. The third and remaining state with a civil service provision is its fundamental law is Colorado, where article 20 , section 3 places the police and fire departments of Denver under the protection of such civil service regulations as are to be established by the city charter.

- 46 Pa. Super. Ct. 573. 
The various state legislatures have frequently enacted civil service laws, covering at times all the state, county and city employees, and on other occasions only the civil service of a city or class of cities, or possibly merely the police and fire departments of a city. Instead of an act of the legislature, in at least one instance, a city with 30,000 inhabitants dwells under the protection of a civil service system based solely upon an ordinance adopted by the city's legislative hody. Newport, one of Kentucky's cities which has the commission form of government, adopted on January 22, 1912, an ordinance establishing a complete civil service system.

\section{III}

While civil service systems thus trace their origin to different legislative sources, they also fall into a new series of groups with respect to the scope of the positions included within each system.

Four states have civil service laws which cover not only the state service, but officials of the cities and counties as well. The tendency towards dissimilarity in form of law is again apparent and these four states represent four different systems of administration of the civil service principles. The oldest law is that of New York enacted on May 4, 1883, under which a state commission appointed by the governor has direct charge of the civil service of the state, counties and villages and has. supervisory control over a series of forty-seven local civil service commissions, one for each city, appointed by the mayor, except in exceptional circumstances when the state commission may appoint the local commissioners. In practice the system is unwieldly and there is a certain lack of uniformity in the rules and administration of the law by the various local commissions. The commission in New York City operates under the general law supplemented by a series of civil service provisions of the charter of Greater New York City.

The next oldest state civil service act is that of Massachusetts which became a law on June 3,1884. The dual system of a state and many local commissions is maintained, but all the work is centralized and the state commission in fact has the entire responsibility in the administration of the law.

The third act of this group is that of April 10, 1908, of New Jersey. Local commissions are done away with altogether and a single state commission alone is in charge of the law's administration. One important feature of the New Jersey act may be here mentioned,-that while it applies immediately to the state service, it takes effect in cities and counties only upon adoption at an election by the voters of each of these communities. The Court of Errors and Appeals of New Jersey in Booth v. McGuinness, in upholding the constitutionality of the law as a whole,

.75 Atlantic Reporter 455. 
decided that that provision of the act was unconstitutional which enabled the council, instead of the voters of a city, to adopt the law, and make it apply thereafter to the civil service of such city.

One of the most recently established state systems covering the state service and that of cities and counties is the law of Ohio, which became effective on January 1, 1914. Here there has been a return to the dual system, but the state commission has charge of the civil service of the state and of the counties while in each city a local commission administers the law as to employees in the service of the city and in the school district which corresponds to the city. Doubtless the maintenance of the local city commissions is due to the influence of the existing civil service commissions in Columbus, Cleveland and other Ohio cities.

There are five other state civil service laws which properly form one group, since each covers only the state service, Wisconsin and Illinois, enacted in 1905, Colorado in 1907 and California and Connecticut in 1913. In these states the operation of civil service systems had first been tried out by local municipal commissions, which were allowed to continue their work without interference upon the enactment of the state law. One result has been the multiplication of commissions, there being eight in California and five in Colorado, while in Illinois there are at least eight commissions representing five separate civil service systems, a state civil service commission; one for each city adopting the municipal civil service law, Chicago, Evanston, Springfield and Waukegan; separate boards administering civil service in the fire and police departments of cities of from seven to one hundred thousand which have adopted a certain act, Aurora, Joliet, Rockford and Elgin; a commission having charge of the civil service in Cook County, and finally another with jurisdiction over the West Chicago Park employees. There is apparently an unnecessary duplication of work in maintaining so many commissions when a consolidation is possible. The New Jersey system of one commission doing all the work for the state, counties and cities shows the possibilities of a single comprehensive system of civil service in a particular state.

\section{IV}

The cities of the United States which are under civil service may be divided into numerous important groups, according to the nature and source of the civil service provisions of their charters, and also according to the form of government, whether modeled upon the old pattern or after the new commission type. The lines of cleavage cross each other and a particular city may be found in two or more of the groups. A fundamental distinction separates cities whose machinery of government is provided for by general or special laws of the state legislature from those which enjoy more or less autonomy resulting from "home rule" charters which have been drafted and adopted by the voters of the 
municipality. California, Colorado, Michigan, Minnesota, Missouri, Oklahoma, Oregon and Washington allow within certain limits some of their cities the privilege of adopting charters of this type. Each city, to a limited extent, is free to select its own form of local government, including the privilege of recognizing or ignoring such principles as that of basing civil service on the merit system. By no means all of the home rule cities have adopted civil service and eliminated the spoils system, but where the merit system has been resorted to it necessarily has been by the voluntary action and choice of the community. Among the more important cities with home rule charters, which have incorporated therein civil service principles, may be mentioned Denver, Kansas City (Missouri), Los Angeles, Oakland, Pueblo (Colorado), Sacramento and San Francisco.

The civil service provisions of the charters of these cities differ widely among themselves and in instances present unusual features. Thus in Pueblo the civil service commissioners are elected by the voters and are subject to the "recall." Los Angeles has five civil service commissioners, almost the only instance in the country of such wide departure from the usual type of a commission of three members. In Denver the members of the police force are by the state constitution directly placed under civil service, while in Missouri, policemen are considered as state officers so that in Kansas City the police department is excluded from the jurisdiction of the civil service commission.

The point of view shifts when we turn from cities with home rule charters to those whose form of government is provided by the statelegislature. In the former case the community may recognize that it needs the merit system, in the latter the legislature as a paramount authority may decide that certain municipalities should have civil service instead of the spoils system. A community conscious of its troubled politics may itself seek relief or the fatherly legislature may insist upon its getting relief from the spoils system.

The legislative will may be expressed by special laws for particular localities as is exemplified by the civil service law of New Orleans, and by the charter of Greater New York City with its numerous clauses referring to the civil service, and also by the host of special and local civil service enactments with which the Massachusetts legislature has confusedly built up its complicated system. The reasons are not clear for state legislation to the effect that druggists shall be eligible like normal citizens for appointment to public office (Acts 1912, chapter 212, page 139), or that assistant watchmen in the state prison must be between twenty-five and forty years when appointed (Acts 1899, chapter 245). Massachusetts may be considered to be farthest away from the home rule charter cities in spite of its own early history when each of its towns was sufficient in all things unto itself.

The present tendency is away from state interference in local affairs 
by special legislation. Municipalities are classified by population and laws passed for each class. Frequently, however, there is only one city of the most important class and the practical effect is to allow legislation for such city under the paraphrase "every city of the first class." This is the way the Pennsylvania legislature refers to Philadelphia. In this state also there are only two cities of the second class, Pittsburgh and Scranton, which are incongruously yoked together although one is four times the size of the other. In addition to these Pennsylvania cities, Milwaukee may be mentioned as having a civil service law enacted for cities of a certain class, in effect meaning one particular chief city, while the recent act of March 25, 1913, creating a civil service commission in Minneapolis applies in terms to all cities of the first class not organized under a certain section of the state constitution.

Elsewhere civil service laws for particular classes of cities may apply to a substantial number of municipalities, for instance the law adopted by referendum by Chicago, Springfield, Evanston and Waukegan in Illinois, and the commission form of government law containing civil service provisions which has been adopted likewise by referendum by Des Moines, Cedar Rapids and several Iowa cities. Civil service laws applying only to police and fire departments may be mentioned in this connection, such as those adopted by Milwaukee in Wisconsin and Rockford, Aurora, Joliet and other cities of Illinois.

It is to be noted that practical experience shows that when there is only one city in a class the representatives of that city in the legislature generally have a controlling voice in all legislation affecting such city. Bearing this fact in mind it is manifest that in every one of the municipalities under discussion civil service has been adopted only at the instance of the local community, either by including the merit system as part of the home rule charter as in the California cities, or by referendum adopting the provisions of a state law applying to several cities, such as that of Illinois, or by procuring special legislation for such city either directly as in New Orleans, or under the guise of laws for "every city of the first class," as in Philadelphia. This generalization applies to nearly all cities in the country except those of New York and Ohio and possibly of Massachusetts. It is in New York and Ohio that there are constitutional provisions directing that the merit system is to be established throughout the state, thereby including the cities, and the voters of the municipalities are in no wise consulted except as members of the commonwealth adopting or rejecting the state constitution.

While the people of the United States have not yet decided as to the extent to which the state legislature should interfere with the local government of municipalities, it would seem that the principles of civil service are of such fundamental importance that the state as a whole may properly be interested in the question whether the spoils system is to be allowed to 
exist in any of its sub-divisions. Although communities drafting home rule charters frequently recognize the importance of civil service principles the tendency at the present time may be said to be towards the enactment of complete systems of civil service covering not only state employees but those of municipalities and other sub-divisions of the state. Frequently the need for civil service is first recognized as to municipal employees and the system is extended to state employees only after local commissions have been in operation for several years.

\section{$\mathrm{V}$}

Another fundamental distinction for the classification of cities relates to the form of government. The commission government cities form an important group distinct from those with the old established bicameral numerous councils. This younger group contains representatives of every one of the types of cities already mentioned. Des Moines and other Iowa cities have adopted by referendum the uniform commission form of government act in which the civil service system is embodied. Springfield (Illinois) has by referendum adopted two general laws, one establishing the commission form and the other covering civil service. New Orleans was already provided by a special act of the legislature with a civil service system when it recently was given the commission form of government. In that city the civil service system was left unimpaired, practically the only change being in the designation of officials who should form the civil service commission. Oakland (California), Pueblo (Colorado), and Sacramento (California), are home rule cities with civil service provisions incorporated in their charters. Newport (Kentucky) is a commission city in which the city council has adopted an ordinance establishing a comprehensive system of civil service. Grand Junction (Colorado), a city of 7,700 inhabitants is at one and the same time trying three twentieth century remedies for political evils, the commission form of government, civil service and a system of preferential voting which is a modification of the proportional representation plan which was recently discussed in the R Rview. [Footnote. See issue for January, 1914, p. 49.]

No two laws for the establishment of commission government in cities are identical in their civil service features. In Des Moines the city council elects the civil service commission. In Pueblo the people elect the members. In Keokuk and the smaller Iowa cities the city council themselves act as civil service commissioners, while in New Orleans, the mayor and two of the city council designated by the entire council act as the civil service commission.

Out of 186 cities reported as having the commission form of government, on January 1, 1913, forty-five appear to have civil service principles incorporated in their charters or laws. But when only cities of 
fifty thousand inhabitants and upwards are considered, out of twentyone such cities, two-thirds are found to be under the merit system.

VI

Turning to counties which are under the civil service, we find that there are three well-defined types of laws. The state-wide laws of Ohio, New York, Massachusetts and New Jersey cover county employees, in each instance the state commission having direct charge of the enforcement of the law. In the first three states named the law is mandatory, while in New Jersey the voters of a county may adopt the civil service law. A second group consists of cities large enough to include a coterminous county, such as Denver, and San Francisco, in each of which the municipal civil service commission administers the law for the benefit of city and county employees alike. This plan is in contrast with that in force in Philadelphia where the civil service law applies only to city office holders, positions which are technically county offices, although essential parts of the government of the municipality, not being covered by the law.

Finally, Cook County, Illinois, has a separate civil service commission under special acts of the legislature. In view of the fact that there also is a separate civil service commission for the West Chicago Park system, the reason for this duplication of machinery is not apparent.

While counties are generally recognized as being convenient units for the administration of justice and the establishment of separate courts, no demand is apparent through the country for the creation of separate civil service commissions for the various counties. The Couk County law was enacted in 1895 and the present tendency appears to be toward the extension of civil service principles to the employees of counties by placing the work of administering the law in the hands of a single state commission instead of numerous local commissions, yet it must not be forgotten that on November 5, 1912, the voters of Los Angeles County adopted a bome rule charter containing a civil service system.

\section{VII}

It is not possible here to touch upon the detailed provisions of the various civil service laws such as those relating to the classification of the service, the scope and character of examinations, and the several systems of keeping efficiency records. These matters present many interesting questions and would serve as further illustrations of the versatility of the American people in their endeavor to devise thorough yet practical systems of automatically selecting honest and efficient public servants according to their merits rather than their politics. Restricting our inquiry to the origin and general jurisdiction of the various civil service systems, we find that there has been in recent years a marked increase in the rate at which the principles of civil service are being extended and 
applied throughout the country. During the legislative period commencing January, 1913, three of the states enacted comprehensive state-wide civil service laws-California, Connecticut and Ohio-so that there are now nine states with such laws with a promise of a steady increase in the number from year to year.

Generally speaking the need for civil service is first felt in the largei cities and in response to the demand a system is established locally with a municipal commission as the administrative body. With the exception of St. Louis every one of the twenty largest cities of the United States now has civil service as part of its machinery of municipal government. After local commissions have been established for several years, the tendency is to extend to the state service the system which experience shows has produced locally beneficient results. When the state civil service law is enacted the work of the municipal commissions is frequently allowed to be further carried on locally instead of placing the entire administration of the law in the hands of a single state commission. Such has been the course in Ohio and California, although in New Jersey a single commission conducts the examinations for appointments to positions in the service of cities and counties as well as of the state itself.

There is a distinct advantage in centering the responsibility for the administration of an entire state system in the hands of one commission, since a commission should be freed as far as possible from subserviency to the officials over whose political ambitions and actions it may be designed to act as a check. If the civil service law is administered by the appointees of a mayor who are subservient to his political demands, the system may become an instrument of confusion and a means of defeating the very purpose for which the law was passed. If the civil service commission is subject to manipulation and improperly stamps its approval upon actions which amount to deliberate discriminations in favor of the adherents of a particular political party, the people, lulled to security by the apparent fairness of the law, may be in a worse condition than if their vigilance had been maintained by the absence of such legislation. This contingency will probably occur but rarely, nevertheless, the single state commission is generally beyond the reach of local political influence and is more responsive to a healthy public opinion insisting upon a just and impartial administration of the law. In seeking the best men to act as civil service commissioners, we find ourselves face to face once more with the old problem of democracy in America, as to the proper means of securing men just and capable of administering the law and the machinery of government. 